\section{NEW LOCALITY RECORDS OF THE 'DANCING GIRL' OF MIZORAM, A RARE ZINGER SPECIES}

\author{
Aparajita $\mathrm{De}^{1} \&$ Demsai Reang ${ }^{2}$ \\ 1,2 Department of Ecology and Environmental Science, Assam \\ University, Silchar, Assam 788011, India \\ 19aparajita.dehajra@gmail.com (corresponding author), \\ 22demn000@gmail.com
}

The genus Mantisia Sims. (Zingiberaceae) comprising of only four species viz., Mantisia spathulata (Roxb.) Schult., Mantisia radicalis (Roxb.) D.P. Dam \& N. Dam, Mantisia wardii B.L.Burtt \& R.M.Sm. and Mantisia wengeri C.E.C. Fisch. is found in the hilly areas of the northeastern India and Myanmar (Dam et al. 1997). In India, the species, Mantisia spathulata is found in Mizoram. It is commonly called the 'Dancing Girl'. The species is considered as critically endangered (Sharma et al. 2012). Due to natural calamities and anthropogenic activities, $M$. spathulata has become critically endangered in nature and has reached such a level that only a few individuals are available today and the species has been included in the national priority list for its recovery by the Department of Biotechnology, New Delhi (Sharma et al. 2011). Bhowmik et al. (2010) reported that Mantisia wengeri was traditionally used to cure bone fractures and gastrointestinal ailments. The paper also mentions that no phytochemical screening has been done to study its active compounds due to its extreme rarity. Williams et al. (2004), using molecular biological data, suggested that Mantisia be nested within Globba and the four species of Mantisia be formally transferred into Globba but retained as a distinct section. The genus Mantisia has been classified with Globba under the tribe Globbeae but in different sections Mantisia and Globba respectively. Numerous cytological studies conducted on Globba and Mantisia suggested that $x=8$ is the base number for Globba and $x=10$ for Mantisia (Williams et al. 2004).

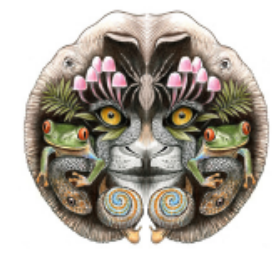

ISSN 0974-7907 (Online) ISSN 0974-7893 (Print)

\section{OPEN ACCESS}

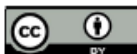
We therefore treat the species under the genus Mantisia in the light of the above observations.

M. spathulata is a perennial plant and flowers for a very short time during the monsoon period. Dam et al. (1997) noted that the species is found only in the rocky hills of Lunglei, Mizoram at 1200-1500 m. Bhowmik et al. (2010) found that M. spathulata blooms in its natural habitats during May 2007 on the rocky hills along the roadside of Lunglei, Mizoram at an elevation of about $1395 \mathrm{~m}$. We, however, collected the species at a comparatively lower altitude approximately at $662 \mathrm{~m}$ from Kolasib, which was never recorded earlier. The present study deals with the information of a new site discovered for M. spathulata and its population density.

\section{Mantisia spathulata}

(Roxb.) Schult., Mant. 1: 49. 1822. Globba spathulata Roxb. FI. Ind. (Eds. Carey \& Wall.) 1: 83. 1820.

Stems 3-6 dm high, purplish at base. Leaves 0-25 $\times 3.5-5.5 \mathrm{~cm}$, glabrous, purplish beneath when young, becoming green in age. Panicles $0-25 \mathrm{~cm}$ long on ca. $5 \mathrm{~cm}$ long peduncle; branches numerous, approximate, villous; bracts ca. $1 \mathrm{~cm}$ long, pale violet. Calyx ca. $6 \mathrm{~mm}$ long; lobes ovate, ca. $2 \mathrm{~mm}$ long, apex acuminate.

DOI: http://dx.doi.org/10.11609/jott.2051.8.5.8841-8843

Editor: P. Lakshminarasimhan, Botanical Survey of India, Pune, India.

Date of publication: 26 May 2016 (online \& print)

Manuscript details: Ms \# 2051 | Received 30 May 2015 | Final received 06 May 2016 | Finally accepted 10 May 2016

Citation: De, A. \& D. Reang (2016). New locality records of the 'Dancing Girl' of Mizoram, a rare Zinger species. Journal of Threatened Taxa 8(5): 8841-8843; http:// dx.doi.org/10.11609/jott.2051.8.5.8841-8843

Copyright: @ De \& Reang 2016. Creative Commons Attribution 4.0 International License. JoTT allows unrestricted use of this article in any medium, reproduction and distribution by providing adequate credit to the authors and the source of publication.

Funding: Assam University and DST, India [DST No: SERB/F/2489/2011-12 dated 02. 03. 2012].

Conflict of Interest: The authors declare no competing interests.

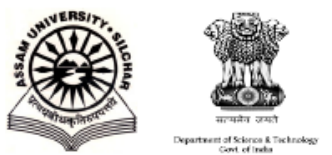

Acknowledgements: The authors duly acknowledge Dr. P.K. Hajra, Ex-Director Botanical Survey of India, who assisted in identifying the species. They also acknowledge the funding assistance received from DST FASTTRACK project for conducting the study. 
Corolla hairy outside; tube $1.5-1.8 \mathrm{~cm}$ long; lobes $4-5$ $\mathrm{mm}$ long, dorsal ca. $4 \mathrm{~mm}$ broad, laterals ca. $3 \mathrm{~mm}$ above the corolla mouth, ca. $6 \times 3 \mathrm{~mm}$. Lip obovate, $6-8 \mathrm{~mm}$ long, yellow, base cuneate, hairy, apex divided into two $2-3 \mathrm{~mm}$ broad lobes. Anther filament $1.5-1.7 \mathrm{~cm}$ long, curved; anther ca. $2 \mathrm{~mm}$ long, wings semi-lunar, ca. $1.5 \mathrm{~mm}$ long, crest quadrate, ca. $0.8 \mathrm{~mm}$ long. Ovary oblong, pale violet.

Flowering: April-June.

Specimen examined: (Demsai Reang 4), 27.v.2014, Mizoram, Kolasib, $24^{0} 11.316^{\prime} \mathrm{N} \& 92^{\circ} 41.624^{\prime} \mathrm{E}$, ca. $662 \mathrm{~m}$ elevation.

Distribution: Assam (Cachar), Meghalaya (Khasia \& Jaintia Hills), Mizoram (Mizo Hills); Bangladesh. Myanmar.

Ecology: A survey to search for the species, $M$. spathulata, was conducted in the months of AprilMay 2014, in Mizoram. The species was discovered at Kolasib $\left(24^{\circ} 11.316^{\prime} \mathrm{N} \& 92^{\circ} 41.624^{\prime} \mathrm{E}\right)$, Mizoram at an altitude of $662 \mathrm{~m}$ (Image 1). Species found was sampled to study its population density. Density study was done using quadrat method. Plotting was done for the adult individuals (with flowers) using quadrat size of $1 \times 1$ $\mathrm{m}^{2}$. A total of 10 plots $\left(1 \times 1 \mathrm{~m}^{2}\right)$ were laid. All adult individuals falling within the plot quadrat were counted. Again, a $1 \times 1 \mathrm{~m}^{2}$ plot was laid to count the juvenile (without flowers) individuals of the species to see their regeneration status in the wild.
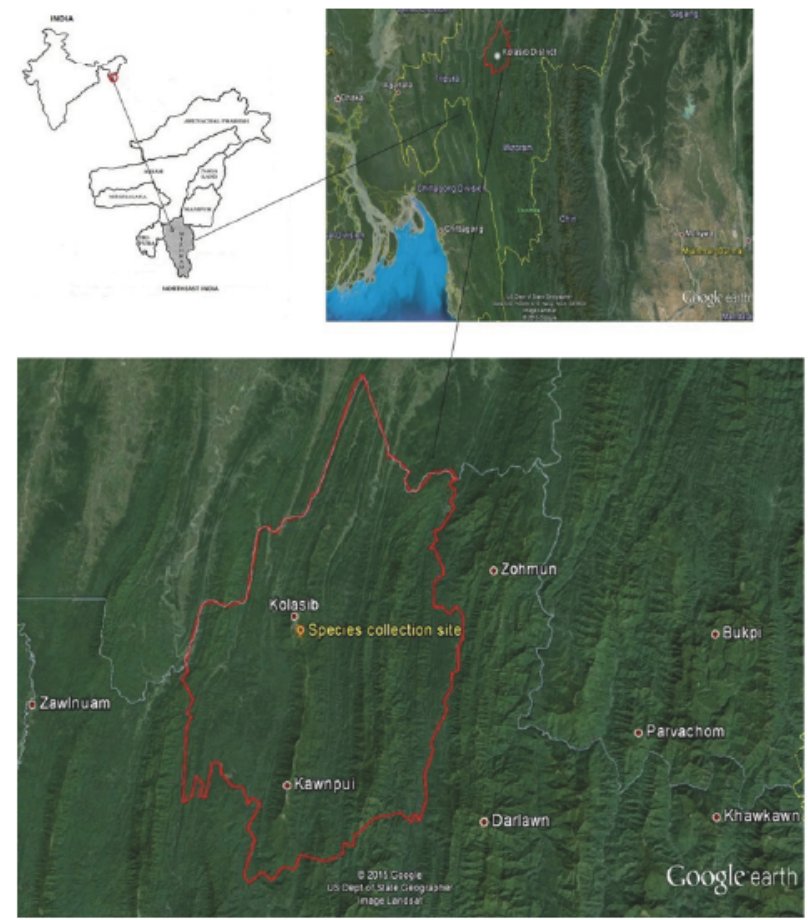

Image 1. Map of study site.
It was observed that the species was growing only in a single large patch along with other species. The size of the patch area where the plant was found growing was approximately $30 \mathrm{~m}$ in length and width of the area was approximately up to $6.5-7 \mathrm{~m}$.

The average density of $M$. spathulata within its growing patch was $18( \pm 2)$ individuals per $\mathrm{m}^{2}$. The patch revealed that all the plants were healthy and were regenerating very well. An approximate number of ca. 120 juvenile individuals (without flowers) were recorded from a $1 \times 1 \mathrm{~m}^{2}$ plot; thus indicating vigorous regeneration. The species was collected and after processing it was deposited in the herbarium of Department of Ecology \& Environmental Science, Assam University (Image 2).

The other associated species growing along with Mantisia were Ficus sp., Adiantum lunulatum, Vitis sp., Lantana camara, etc. The species was seen to be growing in an open rocky area covered with mosses, ferns and climbers (Image 3). It was thriving best amidst ferns and mosses.

Two interesting observations were noted. First, the individuals were found to inhabit very specific areas. They were found in very few numbers in bare rocky



Image 2. Herbarium sheet of Mantisia spathulata 

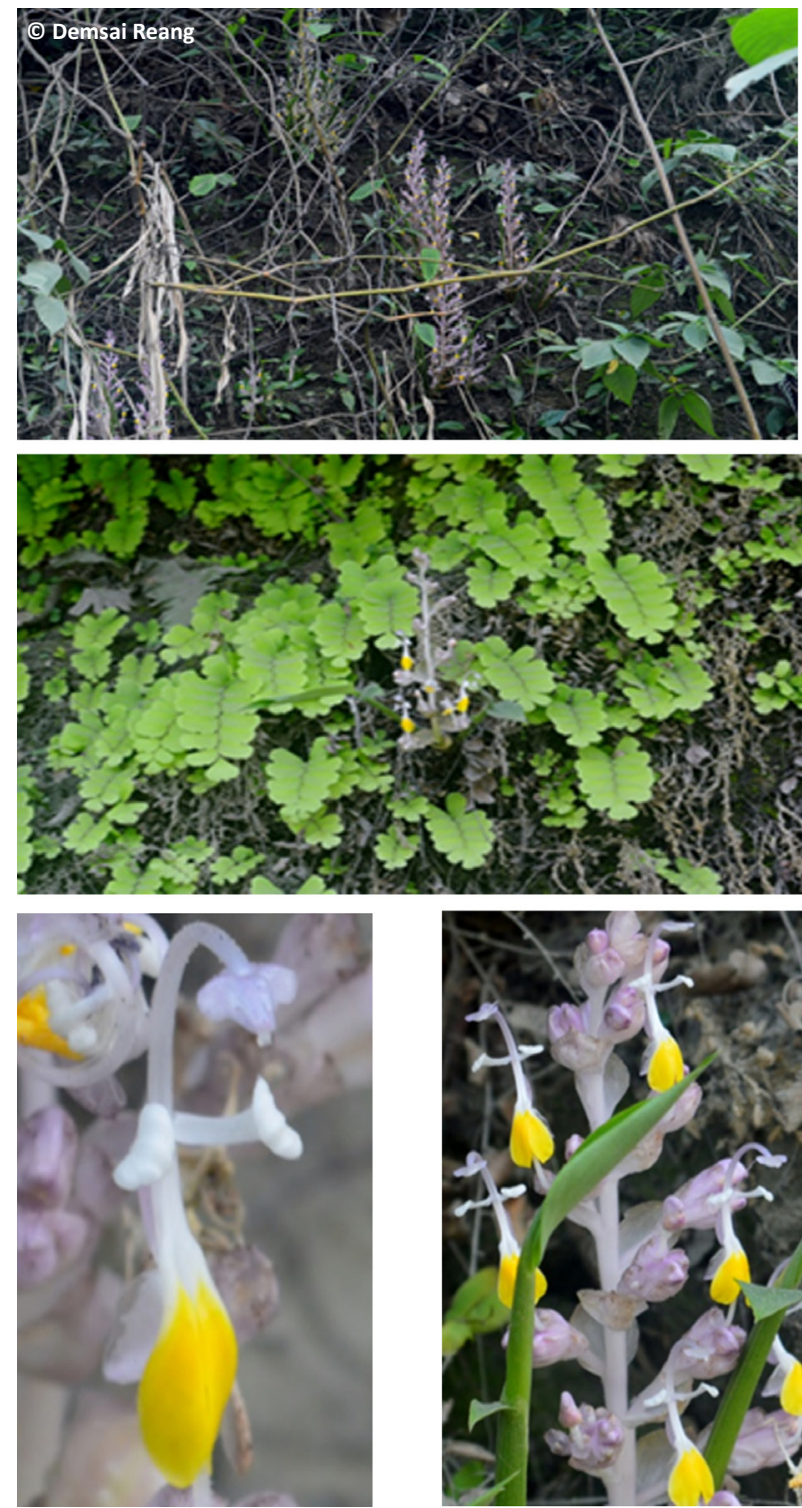

Image 3. Habitat, associated species and individual inflorescence of Mantisia spathulata at study site.

surface where the associated species were absent. Second, the individuals were also conspicuously absent in the dense patches of vegetation adjacent to the study site. This indicates the species requires optimum amount of sunlight and shade and the presence of specific associated species as mentioned above. These factors were the major determinants for the growth of this species in the wild. However a detailed study regarding the habitat specifications in the future is required to ascertain the growth of this species in the studied locality.

The locality is currently undergoing extensive land degradation since it is very close to the road. It was observed that the habitats of the plants had severely eroded at different places due to slope failures and landslides. The slope where the plant was found is highly degraded. Hence steps should be taken to preserve this new locality of this rare species. Some methods to ensure conservation would be the restoration of the patch so that further habitat degradation is checked. Also the species may be grown under ex situ conditions and then reintroduced into other suitable habitats. Such habitats could be selected by applying Ecological niche modelling techniques (Liu et al. 2006). Also further research may be done to investigate the reason for occurrence of this species at a lower altitude.

\section{References}

Bhowmik, S.D.S., S. Kumaria \& P. Tandon (2010). Conservation of Mantisia spathulata Schult. and Mantisia wengeri Fischer, two critically endangered and endemic Zingibers of Northeast India. Seed Technology 32: 57-62.

Dam, D.P., N. Dam \& R.M. Dutta 1997 (1992). Mantisia saltatoria Sims versus Globba radicalis Roxb. (Zingiberaceae). Bulletin of the Botanical Survey of India 34: 188-193.

Liu, Z., L. Kewei, C. Lijun, L. Sipeng, L. Liqiang, S. Xiaochun \& H. Laiqiang (2006). Conservation ecology of endangered species Paphiopedilum armeniacum (Orchidaceae). Acta Ecologica Sinica 26(9): 27912799; http://dx.doi.org/10.1016/S1872-2032(06)60043-7

Sharma, S.K., S. Kumaria, P. Tandon \& S.R. Rao (2011). Synaptic variation derived plausible cytogenetical basis of rarity and endangeredness of endemic Mantisia spathulata Schult. The Nucleus 54(2): 85-93; http://dx.doi.org/10.1007/s13237-011-0033-

Sharma S.K., S.S.D. Bhowmik, S. Kumaria, P. Tandon \& S.R. Rao (2012). Low genetic diversity as revealed by SPAR methods possibly leads to extinction of two critically endangered and endemic species of Mantisia. Biologia Plantarum 56(2): 292-300; http://dx.doi. org/10.1007/s10535-012-0089-z

Williams, K.J., W.J. Kress \& P.S. Manos (2004). The phylogeny, evolution, and classification of the genus Globba and tribe Globbeae (Zingiberaceae): appendages do matter. American Journal of Botany 91(1): 10-114; http://dx.doi.org/10.3732/ajb.91.1.100 